\title{
The Effect of the Tuning System and Instrument Variables on Modal Dictation Performance
}

\author{
Rasim Erol Demirbatır ${ }^{1}$, Hatice Çeliktaş ${ }^{1}$, Doruk Engür ${ }^{1}$ \\ ${ }^{1}$ Uludag University, Turkey \\ Correspondence: Hatice Çeliktaş, Uludag University, Turkey.
}

Received: October 24, 2017

Accepted: December 19, 2017

Online Published: December 28, 2017

doi:10.11114/jets.v6i1.2726

URL: https://doi.org/10.11114/jets.v6i1.2726

\begin{abstract}
Ear training and musical literacy (ETML) education is one of the main dimensions of the bachelor degree program of music teacher education departments, which provides professional music education. In ETML education, hearing, sight-reading and dictation studies for Turkish music makams have an important place. In this study, it was aimed to investigate the effects of different instrument sources and tuning systems; namely, equal tempered or traditionally tempered, on the modal dictation performances of students in dictation exercises in the scope of ETML education. This research was conducted with 56 bachelor degree music education students who were taking ETML course. While equal tempered and traditional instruments (piano and kanun) were used as the sound source in the research, examples of equal difficulty level in Huseyni makam scale, which is one of the main makams of Turkish music, were used as dictation material. Both instruments were tuned in accordance with both the equal temperament and the traditional makam system so that four different dictation types were created. As a result of the research, it has been determined that the students are more successful when piano is used in dictation than kanun-dictated trials and in terms of tuning system, the students are found to be more successful with equal tempered system when compared with traditional tuning system. The instrument and tuning interaction was not statistically significant.
\end{abstract}

Keywords: ear training, Turkish music, tuning systems, melodic dictation, modal dictation

\section{Introduction}

Through musical education, which is defined as bringing musical behaviors for certain purposes through a person's own experience and changing these behaviors in a certain way through their own experiences; it is aimed to meet the aesthetic needs of the society as well as the individuals, to develop the musical taste, to satisfy the artistic creation instinct, to make the musical life more healthy, more effective and productive (Ucan, 2005; Say, 2005).

Music education is divided into three types as general, amateur and professional music education with different purposes and functions. Professional music education, which is one of the types of music education, is carried out in a comprehensive way in Turkey and holds an important place. Professional music education is carried out from primary education to higher education at State Conservatories; at the level of secondary education in Fine Arts and Sports High Schools; in the Higher Education State Conservatories as well as in the Music Teaching Programs of the Faculty of Education and in the Music Departments of the Faculty of Fine Arts.

Ear training and musical literacy (ETML), voice and instrumental education, which are included in the scope of music education in the schools that provide professional music education, take place in the first place (Ucan, 2005) and moreover, among these aforementioned courses, ETML education is the basis for the activities to be carried out in a healthier and correct way. Ucan (2005) defined ETML education as "the ability to perceive, recognize, remember, distinguish, solve and analyze perceivable musical whole, elements, materials, features and relations with hearing sense". This course, which has been included in the curriculum in 2007 by the Higher Education Institution (HEI) under the name of ear training and musical literacy in the Music Teaching Program of the Teacher Training Undergraduate Programs of the Education Faculties provides students with theoretical knowledge about music, musical hearing, musical reading, musical writing, musical thinking, musical creation, musical analysis, musical evaluation skills (Aydogan, 1998, as cited in Er, 2012). In the Music Teacher Training Program, which is prepared by HEI, ETML education continues for 6 semesters and it is seen that the contents of the course are very intensive and comprehensive.

In addition to the tonal music in the program where music theory and musical reading and writing are performed in 
parallel, Turkish music makams and scales (only in equal temperament), pentatonism, medieval music and modes, jazz music and scales, 20th century music, and the various systems, which have different structures are included. In practice, studies with tonal music, especially with respect to Turkish music makam and scales, take place widely and are processed for 5 semesters. In the scope of this education; various practices such as one-voice and two-voice sight reading, melodic dictation, musical analysis and creating applications in Huseyni, Karcigar, Rast, Nihavend, Kurdi, Hicaz, Zirguleli Hicaz, Nikriz, Segah, Huzzam and Saba makams are carried out (Higher Education Board, 2007; Uludag Universtiy, 2015).

Considering the literature on Turkish music makam scales, it is seen that as these subjects are getting more crucial in the curriculum of ETML courses, they are emphasized more on the preparation of related course / teaching materials and the number of course books published increases. Muziksel Yazma Egitimi ve Ezgi Bankasi [Musical Dictation Education and Melody Bank] by Ozgur and Aydogan (2014), Halk Ezgileriyle Solfej [Solfege on Folk Melodies] by Sevgi and Tugcular (2013) which includes samples of folk music in various scales from different regions of Turkey, Turk Muzigi Makam Dizileri [Turkish Music Makam Scales] by Sun (2013), Turk Muzigi Nazariyati ve Usulleri [Turkish Music Theory and Rhythmic Cycles] by Ozkan (2014) whose first edition was published in 1984, Turk Muzigi Nazariyati ve Solfej - I [Turkish Music Theory and Solfege - I] by Tekin (2016) and Turk Muzigi Nazariyati ve Solfej - II [Turkish Music Theory and Solfege - II] by Tekin (2014) are among those publications.

In addition to books related to the subject, it is also seen that the research about the teaching processes has accelerated and especially the studies related to the topic have increased in recent years. Some of the studies made in the recent years about makam applications in ETML education are as follows:

In a study investigating the usability of Turkish folk music melodies in ETML education; folk music melodies are classified via document and content analysis in a way that they methodologically proceeded from simple to advance. At the end of the research, it was reached that the folk music melodies can be used in ETML education due to their rhythmic and melodic structure (Donmez, 2015).

In another study, the views of the lecturers at universities about makam applications in ETML education are collected to determine the resources used for the modal sight-reading and dictation applications and how these applications are included in the courses (Ozturk, 2011). According to the research results; for musical aptitude tests and ETML courses, especially Huseyni, Hicaz and Kurdi makam scales are frequently used, and it has been revealed that the practices on these makam scales have been included into the course. Moreover, it has been mentioned that there is limited resources on the subject; "Turkish Music Executive Series" by Sun, "Solfege by Folk Tones" by Sevgi and Tugcular and "Musical Writing Education and Music Bank" by Ozgur and Aydogan are widely used in ETML courses. The instructors state that they also make use of the materials they have created themselves in their lessons and add that they use Turkish music sources in the traditional structure as well as the resources prepared according to the equal-tempered system. The instructors, who point out that they use traditional instruments in addition to the piano in-class practices, have expressed that they are working both in the equal tempered system and in the traditional Turkish music system in makam practices.

It has been observed that in recent years, the sources that can be used as course materials have started to increase and the interest in research about in-class applications has increased as Turkish music makams have gained more importance in terms of program goals in ETML training in institutions providing professional music education. The learning outcomes for Turkish music makams in ETML training are recognition and theoretical understanding of makams and scales, to be able to distinguish when they hear makam scales; ability to sight-read and dictate melodies in various makams.

In this research, instrument and tuning system (equal temperament / traditional makam system), which is thought to be among the factors affecting student success in modal dictation studies, has been determined as variables. And the effects of these two variables on dictation performance are investigated.

\section{Method}

\subsection{Model of the Study}

In this study a repeated-measures factorial design was employed. Fraenkel, Wallen, and Hyun (2012) describe the factorial design as "an experimental design that involves two or more independent variables (at least one of which is manipulated)". Field (2013) indicates that when these independent variables are measured using the same entities it is called as repeated-measures factorial design. In this study, the ability of the students to dictate melodies that differ according to instrument type and tuning system is examined. In this study, in which the instrument and tuning variables are considered as independent variables, the dictation success score is dependent variable. The instrument variable consists of two levels, piano and kanun. The tuning variable has also two levels, traditional and equal temperament. 
During the data collection stage, all dictates arranged according to both independent variables were performed in one session. Equal-level exams have been selected to ensure internal validity and attention has also been paid to the order of dictations (See Table 1).

\subsection{Sampling}

The research was carried out with a total of 56 students who took ETML course (17 males and 39 females), 29 of whom were freshmen and 27 of whom were sophomores. They were all educated in the Music Education Department of Bursa Uludag University Faculty of Fine Arts Education Department of Music Education.

\subsection{Data Collection Tools}

As a means of collecting data in the research, melodies for dictation prepared by researchers were used. The melodies were written using the Huseyni makam scale.

Ilerici (1981) stated that many makam scales could be produced from the Huseyni makam scale, that there were different characteristic chords on the degrees of the scale, that the majority of the samples of Turkish folk music were in the Huseyni makam, and that this makam reflected the Turkish national character. For this reason, in the Turkish music harmony system he proposed, he chose this makam scale as the main scale. For this reason, the samples belonging to Huseyni makam were included in the research.

Huseyni makam, one of the basit (basic, simple) makams in Turkish music, consists of a Huseyni pentachord in its place (on Dugah pitch), and an Ussak tetrachord on Huseyni pitch.

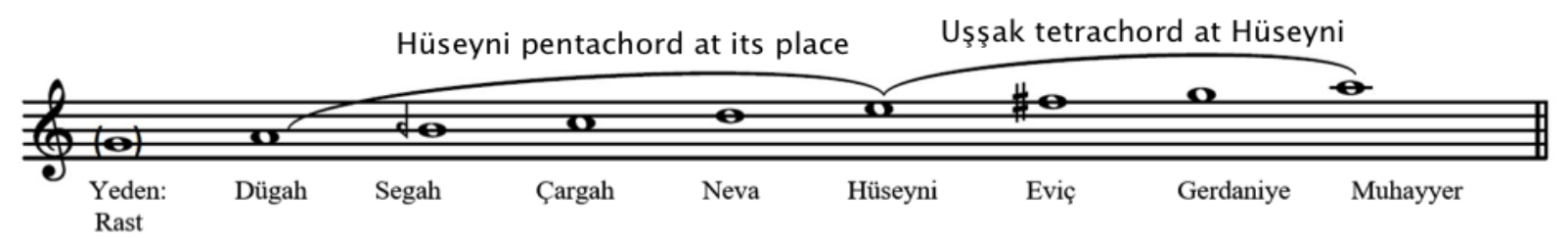

Figure 1. Traditional Huseyni Makam Scale

"Karar" (tonic) of the Huseyni makam is Dugah (A) pitch, its "guclu" (dominant) is Huseyni (E) pitch, and its "yeden" (leading tone) is Rast $(\mathrm{G})$ pitch. Huseyni makam's key signature has a comma (1/9 of a major 2 nd) flat on B pitch and a "bakiyye" sharp (a four comma sharp, 4/9 of a major 2nd) on F. Melodies in Huseyni makam often start on pitches around Huseyni and have both ascending and descending characters. When the scale is descending the Evic pitch ( $F$ with bakiyye sharp) becomes natural $\mathrm{F}$ and called as Acem pitch (Ozkan, 2014; Tekin, 2016).

In practice, piano and kanun were used as sound sources. Kanun is one of the main instruments of traditional Turkish art music and comes from the same roots as the medieval zither or psalterion used in Europe and is defined as the ancestor of the clavichord in some sources. Both instruments were used in equal temperament and also in the traditional tuning system in accordance with the specifications of Huseyni makam. Thus, participants were asked to notate four types of melodies; piano-equal temperament (PET), piano-traditional tuning system (PTT), kanun-equal temperament (KET), kanun-traditional tuning system (KTT).

In order to increase the reliability, three melodies at equal level of difficulty for all types were employed. These 12 melodies $(3 \times 4)$ were chosen from a melody bank consisting of 48 melodies composed by researchers. In selection phase of these 12 melodies, the opinions of the two field experts were taken and in the direction of the opinions received, the materials were given the final shape. Information about instrument and tuning system for the 12 melodies are given in Table 1.

All melodies used in the implementation process are prepared in 4/4 tempo and two measures long, and formed using Huseyni scale.

The melodies, consisting of quarter and eight notes, have the same rhythmic structure (see figure 2) so that participants could give more attention on pitches of the melodies. Moreover, to clarify the rhythmic structure and help participants to feel the beats, a metronome sound on each beat was also added to the melody played.

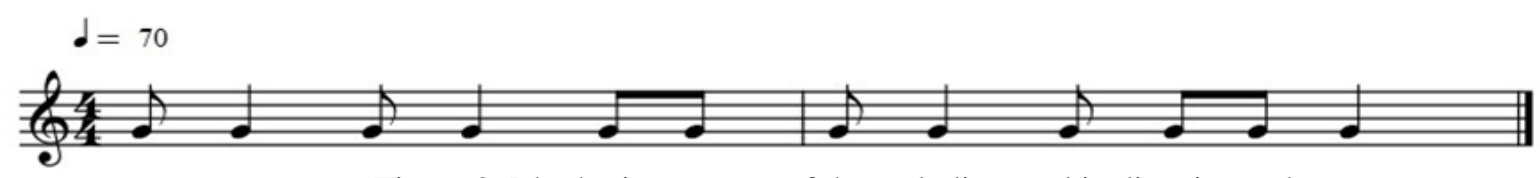

Figure 2. Rhythmic structure of the melodies used in dictation task 
Table 1. Features of the melodies used in dictation task

\begin{tabular}{cll}
\hline No & Instrument & Tuning System \\
\hline 1 & Piano & Equal Temperament \\
2 & Kanun & Traditional \\
3 & Piano & Traditional \\
4 & Kanun & Equal Temperament \\
5 & Piano & Equal Temperament \\
6 & Kanun & Traditional \\
7 & Piano & Traditional \\
8 & Kanun & Equal Temperament \\
9 & Piano & Equal Temperament \\
10 & Kanun & Traditional \\
11 & Piano & Traditional \\
12 & Kanun & Equal Temperament \\
\hline
\end{tabular}

Melodies were recorded as wave files using the software "Mus2 2.1.5.", a notation software for microtonal works and Turkish makam music, and played on a laptop.

In order to determine the reliability coefficient, the correlations between the scores obtained from 3 melodies of the same type were calculated so that 3 correlation coefficients were obtained for a particular melody type. The average of those 3 coefficients were computed and Spearman Brown formula was employed to determine the reliability coefficient for all 4 types of melodies. The calculated coefficients for PET, PTT, KET and KTT are respectively, 0.767, 0.797, 0.748 , and 0.767 .

\subsection{Procedure}

The application was made in one session with all attendees, and the melodies were played on the Logitech S220 $2+1$ speaker connected to a laptop. The response papers given to the participants included written instructions on how the application process would be carried out, and detailed information about the process was also given verbally at the beginning of the implementation.

At the beginning of each dictation work, ascending and descending Huseyni scale was played in traditional tuning or equal temperament system to get the participants prepared for the following melody.

In recent studies, it was seen that the melodies were played at intervals of 30,45 or 60 seconds, according to their difficulty level (Buonviri, 2015; The College Board, 2016). In this study, melodies were played 3 times with 30 seconds intervals as the previous studies were taken into account in the literature, and the participants were given ample time to write their responses.

\subsection{Data Analysis}

All of the 56 participants' answer sheets that participated in the survey were evaluated.

The way in which the dictation performance scores are assessed is as follows:

All melodies used in the implementation process are prepared in 4/4 tempo and two measures long, and all the melodies are composed of 12 notes. For this reason, as a scoring, 1 point was given for each correct pitch and 1 point for each correct note duration like the way prior studies suggests (Buonviri, 2015; The College Board, 2016) and the total score for each melody was determined as 24 points.

Participants were asked to notate 12 melodies. 6 of them were played with piano whereas 6 of them were played with kanun. In each group, half of them were equal tempered whereas the rest is traditionally tuned. Thus, dictation performance scores of each participant were calculated in terms of four main groups (PET, PTT, KET and KTT). In each main group, there are 3 melodies so that the maximum score of each group is 60 ( $3 \times 24)$.

Data obtained for each main group were analyzed using a repeated measures $2 \times 2$ ANOVA, where the factors were instrument (piano and kanun) and tuning (equal temperament and traditional tuning).

\section{Results}

Dictation performance scores of students from melodies created by using different instruments (piano - kanun) and different tuning systems (equal temperament - traditional tuning system) are analyzed and evaluated as follows. 
Table 2. Results of Variance Analysis Showing the Effect of Instrument and Tuning Variables on Dictation Performance Scores

\begin{tabular}{lllllll}
\hline & $S S$ & $d f$ & $M S$ & $F$ & $p$ & $\eta^{2}$ \\
\hline Instrument & 357.54 & 1 & 357.54 & 6.056 & $\mathbf{0 . 0 1 7}$ & 0.099 \\
Residual & 3247.21 & 55 & 59.04 & & & \\
Tuning & 313.50 & 1 & 313.50 & 5.338 & $\mathbf{0 . 0 2 5}$ & 0.088 \\
Residual & 3230.25 & 55 & 58.74 & & & \\
Instrument x Tuning & 96.47 & 1 & 96.47 & 2.200 & 0.144 & 0.038 \\
Residual & 2411.28 & 55 & 43.84 & & & \\
\hline
\end{tabular}

As seen in Table 2, instrument has a significant effect on the dictation performance scores, $\mathrm{F}(1,55)=6.056, \mathrm{p}=0.017$, $\eta^{2}=0.099$. When the tuning variable is ignored, success on melodies played with piano $(\mathrm{M}=56.64)$ is higher than success on melodies played with kanun $(\mathrm{M}=54.12)$.

When tuning variable is considered, table shows that success in equal tempered melodies $(M=56.56)$ is higher than melodies with traditional tuning $(\mathrm{M}=54.20), \mathrm{F}(1,55)=5.338, \mathrm{p}=0.025, \eta^{2}=0.088$.

However, interaction effect between instrument and tuning is not statistically significant, $F(1,55)=2,200, p=0.144, \eta^{2}$ $=0.038$. In other words, difference in scores due to instrument does not change according to tuning system.

Table 3. Descriptive statistics of PET, PTT, KET and KTT scores

\begin{tabular}{lllllll}
\hline Instrument & Tuning & $N$ & $M$ & $S D$ & Skewness $\pm S E$ & Kurtosis $\pm S E$ \\
\hline Piano & Equal T. & 56 & 58.48 & 12.08 & $-0.8394 \pm 0.3190$ & $-0.1953 \pm 0.6283$ \\
& Traditional & 56 & 54.80 & 15.15 & $-0.8737 \pm 0.3190$ & $0.1594 \pm 0.6283$ \\
Kanun & Equal T. & 56 & 54.64 & 13.53 & $-0.5330 \pm 0.3190$ & $-0.6615 \pm 0.6283$ \\
& Traditional & 56 & 53.59 & 13.62 & $-0.4141 \pm 0.3190$ & $-0.5845 \pm 0.6283$ \\
\hline
\end{tabular}

Although interaction effect is not statistically significant, to provide in-depth information, descriptive statistics of variables are given in the table 3. Even though the interaction is not significant, by looking at table it can be seen that using equal tempered system in piano increases the dictation performance scores in the rate of 3.68 (Equal Tempered $=$ 58.48; Traditional Tuning $=54.80$ ), whereas in kanun it increases in the rate of 1.05 (Equal Tempered $=54.64$; Traditional Tuning $=53.59$ ).

\section{Discussion}

Studies on Turkish music makams have an important place in ETML education, which constitutes one of the main dimensions of music teacher education programs in institutions that provide professional music education in Turkey. In the implementation process of those studies, the piano is used as the main instrument.

However, as the piano is an equal-tempered instrument, this can be regarded as a limitation in the performance of the Turkish music makam scales. From this point of view, the main objectives of this study are to determine the effect of the tuning system and using of different sound sources on the dictation performances.

In this aim, dictation performance on melodies written in the Huseyni makam of the participants was investigated in terms of the tuning (traditional and equal temperament) and instrument (piano and kanun) variables and the interaction between them.

It has been determined that the instrument variable has a significant effect on the dictation performance. When the tuning variable is ignored, it has been observed that the dictation performance scores of the melodies played with piano $(M=56.64)$ are higher than the ones played with kanun $(M=54.12)$. It can be concluded that this result is related to ETML being performed with piano and piano being widely used in music education. It should also be taken into consideration that the inclusion of piano education as a compulsory course strengthens the connection between the student and this instrument.

When tuning variables is taken into consideration, dictation performance scores of the equal tempered melodies $(M=$ 56.64) are higher than the scores of traditionally tempered melodies $(M=54.20)$. This can be explained by the fact that students are more accustomed to equal tempered tuning system. It can be said that the use of equal tempered melodies improves the dictation performance because the equal tempered system is used widely during the undergraduate education.

The interaction of instrument and tuning variables has been investigated in order to determine if the effect of tuning variable changes according to the instruments. Since the piano is not a suitable instrument to give sounds in the traditional system, it is expected that the melodies played by the piano will be equally tempered. It is more common for sounds in the traditional system to be heard when the melodies are played with kanun. The data obtained reveals that using equal tempered system in piano increases the dictation performance scores in the rate of 3.68 (Equal Tempered $=$ 
58.48; Traditional Tuning $=54.80$ ), whereas in kanun it increases in the rate of 1.05 (Equal Tempered $=54.64$; Traditional Tuning $=53.59)$. However, this interaction is not significant, $F(1,55)=2.200, p=0.144, \eta^{2}=0.038$. In other words, it cannot be statistically proven that the effect of the equal tempered system in piano on the dictation performance is higher than kanun.

It can be considered that similar studies with more participants will be able to reach significant results. This research is mainly carried out with students of music teacher education program in which the main emphasis is on Western music. Making similar studies in different institutions, with only Turkish music or only Western music educated participants, can lead to different results. The work to be carried out with a larger participant groups will be able to clarify the difference between the tendencies to the tuning systems of Turkish or Western music-educated students.

In this study, it was seen that students were more successful in dictation exercises in which the piano voice was used when compared to kanun. With more extensive studies, students' dictation performances might be examined using different makams and instruments. When all the findings of this study are taken into consideration, it is suggested using different instruments and tuning systems to enrich the applications in music education institutions in the scope of ETML education and increasing the number of the studies related with this field.

\section{References}

Buonviri, N. (2015). Effects of a preparatory singing pattern on melodic dictation success. Journal of Research in Music Education, 63(1), 102-113. https://doi.org/10.1177/0022429415570754

Donmez, A. O. (2015). Turkish Folk Music Melodies, Of Musical Hearing-Reading Training Field Of Music Education a study for availability. Sivas: Cumhuriyet Universitesi Egitim Bilimleri Enstitusu.

Er, A. (2012). Views of teachers' and students' about Turkish music based activities in musical audince reading and writing courses which are taught at music departments in fine arts and sport high schools. Ankara: Gazi Universitesi Egitim Bilimleri Enstitusu.

Field, A. (2013). Discovering statistics using IBM SPSS statistics. London: Sage Publications.

Fraenkel, J. R., Wallen, N. E., \& Hyun, H. H. (2012). How to design and evaluate research in education. New York: McGraw-Hill.

Higher Education Board. (2007). Egitim fakultesi ogretmen yetistirme lisans programlari [Faculty of education teacher training undergraduate programs].

Ilerici, K. (1981). Turkish music and its harmony (2 ${ }^{\text {nd }}$ ed.). Istanbul: Milli Egitim Bakanligi.

Ozgur, U., \& Aydogan, S. (2014). Musical dictation education and melody bank. Ankara: Gazi Kitabevi.

Ozkan, I. H. (2014). Turkish music theory and rhythmic cycles (13 ${ }^{\text {th }}$ ed.). Ankara: Otuken Nesriyat.

Ozturk, B. (2011). Teacher's views on the statution of makam practices in ETML classes. Ankara: Gazi Universitesi Egitim Bilimleri Enstitusu.

Say, A. (2005). Teaching music (4 ${ }^{\text {th }}$ ed.). Ankara: Muzik Ansiklopedisi Yayinlari.

Sevgi, A., \& Tugcular, E. (2013). Solfege on folk melodies. Ankara: Muzik Egitimi Yayinlari.

Sun, M. (2013). Turkish music makam scales ( $3^{\text {rd }}$ ed.). Ankara: Sun Yayinevi.

Tekin, H. S. (2014). Turkish music theory and solfege - II. Ankara: Muzik Egitimi Yayinlari.

Tekin, H. S. (2016). Turkish music theory and solfege - I ( $3^{\text {rd }}$ ed.). Ankara: Muzik Egitimi Yayinlari.

The College Board . (2016). AP music theory scoring guidelines. Retrieved in October 25, 2016, from AP Central The College Board: https://secure-media.collegeboard.org/digitalServices/pdf/ap/ap16_music_theory_sg.pdf

Ucan, A. (2005). Music education ( $3^{\text {rd }}$ ed.). Ankara: Evrensel Basimevi.

Uludag University. (2015). Uludag University information package \& course catalogue. Retrieved in October 2016, from http://bilgipaketi.uludag.edu.tr/Ders/Index/722393

\section{Copyrights}

Copyright for this article is retained by the author(s), with first publication rights granted to the journal.

This is an open-access article distributed under the terms and conditions of the Creative Commons Attribution license which permits unrestricted use, distribution, and reproduction in any medium, provided the original work is properly cited. 